\title{
An entrepreneurial activity implementation and assessment among pharmacy students amid the COVID-19 pandemic lockdown
}

\author{
Elaine V. Nguyen, So Hyun Kim, Mohammed A. Islam, Youngil Chang, Judy Aoyagi, Alamdar Hussain
}

School of Pharmacy, American University of Health Sciences, Signal Hill, California, United States

\author{
Keywords \\ Assessment \\ COVID-19 \\ Entrepreneurship \\ Innovation \\ Learning \\ Shark Tank

Correspondence
Alamdar Hussain
School of Pharmacy
American University of Health Sciences
Signal Hill
California 90755
United States
ahussain@auhs.edu

\begin{abstract}
Objective: To implement and assess innovation and entrepreneurship (IE) learning experience in professional pharmacy students using presentations based on the Shark Tank model. Methods: First-year doctor of pharmacy students were invited to participate in an IE learning experience emphasising the importance of self-care needs of the society during the early phase of the COVID-19 pandemic crisis. Students' proposals were assessed by Sharks (inquisitors) based on a grading rubric, and a post-activity survey captured students' reflections of their experience. Results: Twelve students participated in the IE activity, and presented their proposals virtually in a Shark Tank style format. Students' scores for the proposals ranged from $87.5 \%$ (capable entrepreneurs) to $56.8 \%$ (incapable entrepreneurs), with the winner receiving a gift certificate. Survey ratings given by students on a scale of one to five for the IE activity were overwhelmingly favourable, with both the activity $(4.73(1.09))$ and presentation style $(4.27(0.37))$ viewed to be timely and relevant. Conclusion: An IE learning activity was implemented and assessed in the pharmacy programme using Shark Tank style presentations. The authors believe such initiatives, conducted either virtually or face-to-face, could serve as prototypes for professional pharmacy schools interested in creating exciting ways to implement IE activities in their programmes.
\end{abstract}

\section{Introduction}

Traditionally, innovation and entrepreneurship (IE) in the pharmacy profession has been associated with graduates seeking to establish their niche in the market by opening independent pharmacies with unique service options, which the retail chains lacked (Malcolm, 2016). A survey of 355 participants conducted by Sweaney and colleagues found that $76.9 \%$ of student pharmacists and $62.5 \%$ of recent graduates showed a potential interest in pharmacy ownership (Sweaney et al., 2014). Simultaneously, the constantly evolving dynamics of the patient care setting and increasing roles of pharmacists in clinical practice, compel graduates today to be continually thinking of innovative ways to address new challenges to remain competitive. Brazeau suggested that fostering entrepreneurial spirit in pharmacy students is critical to advance healthcare (Brazeau, 2013).

Entrepreneurship in a broader sense is defined as identifying and creating new opportunities within uncertain business environments (Neck \& Green, 2011). A study performed among pharmacy students over a three-year period concluded that an entrepreneurship course and strong predisposition were the primary factors in IE development (Huston, 2018). Some schools and colleges of pharmacy in the USA have developed programmes to facilitate IE learning among pharmacy students. These institutions provide certificate programmes or entrepreneurial tracks for students interested in acquiring IE knowledge, skills, and mindsets (Mercer University, 2021; Presbyterian college school of pharmacy, 2021; 
Texas Pharmacy, 2021; University of the Pacific, 2021). Nonetheless, not all pharmacy schools are equipped with the requisite resources, nor is it their priority to provide such intensive learning opportunities. Although there are numerous reports emphasising the significance of entrepreneurial development in pharmacy students (Hermansen-Kobulnicky \& Moss, 2004; Huston, 2018; Mattingly et al., 2019a), there are very few studies related to implementation and assessment of IE activities (Laverty et al., 2015; Mogul et al., 2020).

Standards 2016 of the Accreditation Council for Pharmacy Education (ACPE), a national agency for accreditation of professional pharmacy programmes in the USA and elsewhere, incorporates educational outcomes pertaining to personal and professional development. In specific, key element 4.3 addresses engaging pharmacy students in innovative and entrepreneurial activities (Accreditation Council for Pharmacy Education, 2017). Additionally, the 2010-11 American Association of Colleges of Pharmacy (AACP) academic affairs standing committee recognised entrepreneurship as an affective domain trait, thus encouraging students to pursue viable practice models (Mason et al., 2011). Nonetheless, it should be realised that IE should be implemented primarily to nurture student's mindset rather than to merely satisfy the requirement of accreditation bodies. Rosenthal and colleagues commented that the ongoing shift from traditional dispensing to clinical roles is placing substantial stress on pharmacists (Rosenthal et al., 2010). Lack of confidence, fear of new responsibilities, need for approval, and risk aversion are some of the traits they described in pharmacy culture. Pharmacy students must be motivated to broaden their professional horizons and mold themselves to undertake challenges in an ever-evolving practice arena.

ABC (American Broadcasting Corporation) television's award-winning show Shark Tank is popular among viewers because of its unique IE content. In the show, aspiring entrepreneurs showcase their innovative business proposals to a panel of five tough, self-made business tycoons (the Sharks). In turn, the Sharks 'grill' the contestants on the rationale and feasibility of the plan to decide whether to invest their money in the innovation. In pharmacy education, a few groups have demonstrated the implementation of the Shark Tank model in their curricula. For example, Laverty and colleagues offered a workshop that teaches undergraduate pharmacy students about entrepreneurship and evaluated the outcomes using the Shark Tank model (Laverty et al., 2015). Mogul and colleagues implemented and evaluated an innovative clinical service model to solve a pharmacy related issue using the Shark Tank approach (Mogul et al., 2020). However, during the recent COVID-19 pandemic crisis, exploring novel platforms of instilling entrepreneurship skills were the need of the hour. These platforms would have to be virtual while simultaneously catering to the safety and convenience of students.

During the early phase of the pandemic, the co-curricular committee at the authors' institution implemented a virtual learning activity for pharmacy students. It required them to formulate innovative plans, as future entrepreneurs, to address the selfcare needs of the society during the pandemic crisis. In addition, the committee necessitated that plans be delivered in a Shark Tank style format. Thus, the objective of the current study was to implement among pharmacy students a virtual IE learning experience using Shark Tank model-based presentations, and assess its effectiveness on student learning based on standardised grading rubric and student feedback.

\section{Methods \\ Design}

In the final quarter (summer 2020) of their first-year doctor of pharmacy (Pharm.D.) programme, students at the authors' institution were invited to participate in an IE learning exercise. The institution offers a three-year accelerated Pharm.D. programme with each year divided into four quarters of 11 weeks each. Two faculty members explained the significance of this exercise, including presentation style, to the class. Though participation in the activity was optional, it would count toward a student's co-curricular requirement hours in the programme. Twelve students who signed up were given five weeks to research and propose their innovation applicable to healthcare during the pandemic, and to present their business plan in a fiveminute verbal pitch to a panel of five faculty judges, the Sharks (three of whom were co-curricular committee members, and one was from the programme leadership). The Sharks were given guidelines on IE categories and types of questions to ask. The presentations were conducted virtually via the videoconferencing platform, Zoom because the campus was closed in response to state regulations to stay inside homes.

\section{Assessment}

To successfully implement and validate student learning, the co-curricular committee developed an activityspecific grading rubric to evaluate each proposal based on its IE content (Table I). The Center for the Advancement of Pharmaceutical Education (CAPE) outcomes 2013, Domain 4.3 (Innovation and Entrepreneurship) learning objectives examples were 
used as a template to develop the grading rubric (Center for the advancement of pharmaceutical education (CAPE), 2013). Each rubric category contained items critical for entrepreneurial development, which in turn were obtained by a review of literature on entrepreneurship in healthcare professions. The rubric underwent several iterations by committee members to make it applicable to the activity and facilitate the grading process. The judges were oriented to the grading process by two committee members to ensure uniformity in grading for the presentations. The judges independently graded and assigned a percentage score based on points obtained on each of the six sub-domains in the rubric. Membership to pharmacy organisation at a value of USD 250 was awarded to the proposal, which received the highest average score.

\section{Table I: Shark Tank style proposal grading rubric ${ }^{\dagger}$}

\begin{tabular}{|c|c|c|c|}
\hline & $\begin{array}{l}\text { Capable Entrepreneur } \\
\text { (4 points) }\end{array}$ & $\begin{array}{l}\text { Beginner Entrepreneur } \\
\text { ( } 2 \text { points) }\end{array}$ & $\begin{array}{l}\text { No Entrepreneurship quality } \\
\text { (0 points) }\end{array}$ \\
\hline $\begin{array}{l}\text { Proposal: Develop new ideas } \\
\text { and approaches (4.3.2) }\end{array}$ & $\begin{array}{l}\text { The idea is original and unique, } \\
\text { aptly applicable to healthcare }\end{array}$ & $\begin{array}{l}\text { The idea is moderately } \\
\text { innovative, somewhat } \\
\text { applicable to healthcare }\end{array}$ & $\begin{array}{l}\text { Has no clear idea, no relevance to } \\
\text { healthcare }\end{array}$ \\
\hline $\begin{array}{l}\text { Initiative: Motivation to move } \\
\text { the project forward ( } 4.3 .1)\end{array}$ & $\begin{array}{l}\text { Shows persistence, highly } \\
\text { motivated and energetic }\end{array}$ & $\begin{array}{l}\text { Good level of motivation and } \\
\text { energy }\end{array}$ & $\begin{array}{l}\text { Lacks motivation or energy to move } \\
\text { project forward }\end{array}$ \\
\hline Decision making (4.3.3) & $\begin{array}{l}\text { Clearly understands the } \\
\text { problem, shows excellent } \\
\text { decision-making skills }\end{array}$ & $\begin{array}{l}\text { Understands the problem to } \\
\text { some extent, shows good } \\
\text { decision-making skills }\end{array}$ & $\begin{array}{l}\text { No understanding of the problem, } \\
\text { weak decision-making ability }\end{array}$ \\
\hline $\begin{array}{l}\text { Realises one's strengths and } \\
\text { weaknesses (4.3.4) }\end{array}$ & $\begin{array}{l}\text { Fully aware of strengths and } \\
\text { weaknesses }\end{array}$ & $\begin{array}{l}\text { Aware of strengths and } \\
\text { weaknesses to some extent }\end{array}$ & $\begin{array}{l}\text { No clue of one's strength and } \\
\text { weaknesses }\end{array}$ \\
\hline $\begin{array}{l}\text { Applies entrepreneurial skills } \\
\text { (4.3.5) }\end{array}$ & $\begin{array}{l}\text { Has clear marketing plan in } \\
\text { place, fully aware of potential } \\
\text { sources of funding }\end{array}$ & $\begin{array}{l}\text { Has some marketing plan, } \\
\text { knows a few ways to find } \\
\text { funding }\end{array}$ & $\begin{array}{l}\text { No marketing plan in place, no idea how } \\
\text { to find funding }\end{array}$ \\
\hline $\begin{array}{l}\text { Performs risk-benefit analysis } \\
(4.3 .6)\end{array}$ & $\begin{array}{l}\text { Clear understanding of loss- } \\
\text { profit ratio, knows how to } \\
\text { avoid loss }\end{array}$ & $\begin{array}{l}\text { Has some understanding of } \\
\text { loss-profit ratio, knows few } \\
\text { ways of avoiding loss }\end{array}$ & $\begin{array}{l}\text { No idea of loss-profit ratio, no clue how } \\
\text { to avoid loss }\end{array}$ \\
\hline
\end{tabular}

${ }^{\dagger}$ Mapped to CAPE educational outcomes. Numbers in parentheses in first column indicate model examples of learning objectives in sub-domain 4.3 (Innovation and Entrepreneurship). CAPE = Center for the Advancement of Pharmaceutical Education

A 19-item survey instrument developed by the authors included themes of IE learning and student selfassessment of the IE experience. The questionnaire was reviewed and critiqued independently by four faculty members, including a senior Associate Dean for Academic Affairs who has extensive experience in survey designs. A final revised and approved version of the survey instrument was used. The instrument consisted of 14 questions with Likert scale answer choices using the ratings of Strongly Disagree (1), Disagree (2), Neutral (3), Agree (4), and Strongly Agree (5). Five open-ended questions, including one question to comment on reflection and reception of the activity, were part of the instrument.

A link to the online survey instrument (Google forms) was sent to participants via email at the conclusion of the activity. Students were assured of the anonymity of their responses, and thus were encouraged to be honest in their feedback. Two reminder emails were sent out to participants at two-week intervals to ensure completion of the instrument. Since the instrument statements were affirmative in nature, survey responses with an average rating of four and above were considered to have received a high rating, those between three and four were considered to have received a moderate rating, and those below three were considered to have received a low rating.

The study was found to be exempt by the Institutional Review Board of the University. Descriptive statistics were performed using Microsoft Office Excel, and the pool of the quantitative responses are reported as Mean (SD). Thematic analysis of the students' reflections was performed by generating codes and themes as described by Braun and Clarke (Braun \& Clarke, 2006). Two authors of the current paper have recently used this analysis and described it in detail elsewhere (Hussain et al., 2021). The GREET checklist, where applicable, was taken into consideration in the preparation and dissemination of this work (Phillips et al., 2016).

\section{Results}

The students' innovations presented via Shark Tank style pitches were assessed using the grading rubric developed by the committee. Scores assigned to the 
proposals ranged from $87.5 \%$ (capable entrepreneurs) to $56.8 \%$ (incapable entrepreneurs). The questions Sharks posed to the students were categorised into background of the research work, product information, marketing plans, and associated risks. Representative questions posed by Sharks to assess student entrepreneurs are listed in Appendix A. All 12 students who participated in the IE activity completed the survey instrument. In general, ratings given by students for the activity were overwhelmingly positive (Table II). Students indicated that an activity related to the COVID-19 pandemic was relevant to the time $(4.73$
(1.09)), and noted that presenting in the Shark Tank style format encouraged them to think like future entrepreneurs $(4.27$ (0.37)). Other highly rated components of the exercise were: 1 ) The activity enabling the students to think of ways to find funding/ marketing for their product, and 2) The faculty members' roles being viewed as critical in developing IE spirit in them (Table II). Students stated that offering a monetary prize to the winner was not a compelling reason to join the activity. This rating, although in the moderate range, received the lowest mean score on the survey instrument $(3.27(0.27))$.

Table II: Post-activity responses from participants on a scale of one to five (questions arranged in descending order of mean) ${ }^{+}$

\begin{tabular}{|c|c|c|}
\hline \multicolumn{2}{|c|}{ Question } & \multirow{2}{*}{$\frac{\text { Mean (SD) }}{4.73(1.09)}$} \\
\hline 1. V & Working on the concept of patient-care services during the COVID-19 pandemic was relevant & \\
\hline 2. & Presenting my innovation in the Shark Tank style format encouraged me to think like an entrepreneur & $4.27(0.37)$ \\
\hline 3. & Faculty members' roles were important in helping me develop IE spirit & $4.09(0.61)$ \\
\hline 4. & The experience enabled me to think of ways to find appropriate means of funding/marketing my idea/product & $4.09(0.69)$ \\
\hline 5. & I learned how to set a price for an item based on the investment made & $3.91(0.84)$ \\
\hline 6. & The activity consumed a substantial amount of my school/personal time & $3.91(0.65)$ \\
\hline 7. $\mathrm{T}$ & $\begin{array}{l}\text { The amount of time spent on this activity proportionately reflects the amount of new information/attitude I gained } \\
\text { pertaining to IE }\end{array}$ & $3.82(0.45)$ \\
\hline 8. & I feel I can come up with more innovative ideas after participating in this activity & $3.73(0.67)$ \\
\hline 9. 1 & I would recommend this learning experience to students in other classes & $3.73(0.72)$ \\
\hline 10. It & It increased my confidence toward becoming an entrepreneur after participating in this activity & $3.73(0.72)$ \\
\hline 11. I & I have a better understanding of entrepreneurship after participating in this activity & $3.64(0.53)$ \\
\hline 12. I & I learned how to market a product by targeting specific consumers and using advertising & $3.64(0.26)$ \\
\hline 13. I & I had prior knowledge of entrepreneurship before joining this activity & $3.55(0.62)$ \\
\hline 14. Ir & Including a monetary prize to the winner motivated me to join this activity & $3.27(0.27)$ \\
\hline
\end{tabular}

${ }^{\dagger}$ Likert-scale; 1=Strongly Disagree, 2=Disagree, 3=Neutral, 4=Agree, 5=Strongly Agree; $N=12$ responses

Some of the resources which students found to be helpful in researching and developing their projects were articles on the Internet, YouTube video clips, news related to COVID-19, and personal protective equipment product information. Students' 'selfreflection' comments generated themes of 'spreadability of the virus', 'social-distancing', 'affordable protection', and 'creativity' (Table III).

Table III: Participants' responses to open-ended questions

\begin{tabular}{|c|c|}
\hline Question & Responses $^{\dagger}$ \\
\hline 1. What resources were helpful to you in doing your search on IE? & $\begin{array}{l}\text { Websites (50\%); articles (33\%); YouTube video (16\%); commercials } \\
\text { (16\%); personal experience (16\%); friends ( } 25 \%) \text {; news updates }(8.1 \%) \text {, } \\
\text { personal protective equipment product information }(41.6 \%)]\end{array}$ \\
\hline 2. How did you come up with the design of the mask you presented? & $\begin{array}{l}\text { Observed first-line workers (16\%); YouTube video (16\%); personal } \\
\text { experience ( } 25 \%) \text {; group idea ( } 25 \%) \text {; browsing websites }(33 \%)\end{array}$ \\
\hline $\begin{array}{l}\text { 3. How many hours, approximately, did you spend on this innovation } \\
\text { (excluding working on the presentation)? }\end{array}$ & $1.5 ; 4(16.6 \%) ; 5(16.6 \%) ; 9 ; 10 ; 16 ; 48 ;$ did not track \\
\hline 4. What slogan will you use to market your product? & $\begin{array}{l}\text { Swift mask; better to be safe; quality and price; breath right; VirO } \\
\text { facemask; Cas-K; JEAJ makes it better; front line protection }\end{array}$ \\
\hline 5. Student self-reflection themes generated from free-text responses & $\begin{array}{l}\text { Spreadability of the virus, social-distancing, affordable protection, } \\
\text { creativity }\end{array}$ \\
\hline
\end{tabular}

${ }^{\dagger}$ Number in parenthesis represents the percentage of participants who indicated the same resource 


\section{Discussion}

In today's economic climate, IE spirit is vital to instil in pharmacy students for driving innovation in healthcare practice. Mattingly and colleagues emphasised the use of the term 'Pharmapreneur' to describe pharmacy entrepreneurs (Mattingly et al., 2019b), and to distinguish them from business entrepreneurs, the goal of whom is chiefly financial profit. For pharmacists, the ability to positively impact patient outcomes and add to the quality of healthcare provided is of paramount importance. Both pharmacy educators and students need to realise the need for entrepreneurship - the identification of and the ability to take advantage of opportunities to create goods and services - to help meet evolving practice challenges (Shane \& Venkataraman, 2000).

With this concept in mind, the co-curricular committee of the authors' institution introduced a virtual Shark Tank style IE learning experience for students. The intent of the learning exercise was to promote IE skills in students by providing an exciting platform to sell their ideas and receive constructive feedback. Although participants could have chosen many areas to work on for their innovation, most resorted to proposing innovative masks to address the shortage of personal protective equipment encountered during the early phase of the pandemic (summer 2020). The Sharks not only challenged students but also motivated them to 'think outside the box.' For instance, students reported that the experience enabled them to find appropriate means of funding and marketing for their idea, and to set a price for the item based on the investment. Such concepts are not routinely envisaged outside the context of entrepreneurship.

Despite the students performing most of the research independently, they did consider the role of faculty to be important in guiding them to develop their innovation during the five-week period (Table II). This finding agrees with an earlier report where students benefitted by the presence of faculty members in their innovation (Laverty et al., 2015). However, students' confidence in becoming entrepreneurs aided by this activity was not as high as expected. Perhaps the reason could be that this was a single short-term activity, and students had not yet been introduced to concepts of business and marketing in the curriculum. Additionally, the participants were first-year pharmacy students who had not yet completed their full coursework and had not yet participated in extensive experiential practices to feel confident. This is further supported by students' responses stating they had little prior knowledge of entrepreneurship. Such IE exercises may be longitudinally incorporated in the programme to bolster students' confidence. It must be realised that in the process of developing an entrepreneurial attitude, it is necessary to become comfortable with criticism and to learn from failures (Brazeau, 2013). Alternatively, it may be possible that students were not confident because they were critiqued. Subsequent exposure to the entrepreneurial process is required to adjust to critique and failure before true confidence accrues in them. These subsequent exposures to students may be conducted every year in the pharmacy programme. For instance, because of its positive experiences, Cofrancesco and colleagues have made Shark Tank presentations a permanent part of their annual educational conference at their institution (Cofrancesco et al., 2017).

Besides making products, the topics for Shark Tank activities could also include business models, service opportunities, and clinical innovations in healthcare (Laverty et al., 2015). Furthermore, a portfolio may be maintained to track students' progress annually in the IE category for those interested in pursuing this field of pharmacy. For the 'self-reflection' question, the responses of students varied from a single line to more than a page (Table III). Based on the themes generated, it is apparent that students primarily reflected on the applicability of their innovation to the self-care needs during the pandemic.

Besides the clinical perspective, it should be realised that IE implementation in the pharmacy programme provides enhanced transferable skills to students. For example, a recent study, which assessed the impact of IE education in a pharmacy setting concluded that about $48 \%$ of students had developed problem-solving skills, about $69 \%$ demonstrated increased communication skills, and $59 \%$ showed increased skills related to 'lateral thinking' (Laverty et al., 2015). Shark Tank type educational modalities may provide effective strategies for enhancing student skills besides promoting IE learning in pharmacy programmes. The Shark Tank forum sets the stage for lively verbal exchanges and learning (Cofrancesco et al., 2017; Baker et al., 2018). Institutions interested in implementing their own Shark Tank style activities must embrace and support creativity, and provide a venue that promotes collegiality along with competition. To challenge students from different perspectives of IE, it might be useful to have Sharks come from various disciplines of pharmacy (practice, administrative, basic science, and possibly from leadership). This approach would also add to the value of interprofessional aspect within the Shark team.

\section{Limitations}

A limitation of this study is the small sample size. To elicit a high response rate from the survey given the 
small group size and to meet the criteria of minimum percentage of responders proposed by Krejcie and Morgan (Krejcie \& Morgan, 1970), participants were reminded twice to complete the survey instrument until all responses were gathered. Another limitation of this study is the lack of pre-activity evaluation of IE understanding among participants. Administration of a pre-activity survey would have more appropriately allowed the authors' to evaluate changes in the students' understanding of IE prompted by participating in this activity. To make up for the lack of a pre-survey, some of the post-activity survey questions were formulated to include phrases such as 'after participating in this activity', or 'before joining this activity'. Offering a monetary prize to the winner was not a primary motivator for students to join the activity (Table II), implying that the participants honestly wanted to learn about IE. Nonetheless, some students may have participated in the experience simply to fulfil the requirement of co-curricular hours, as one student reported spending as little as 1.5 hours on performing the background search (Table III).

\section{Conclusion}

Entrepreneurship has always been a vital component of the pharmacy practice. It is associated with skills that are critical to the development of a wide array of health services both in clinical and community arenas. With newer challenges faced in the field of healthcare every year, there is an ever-increasing demand for IE education, attitude, and skill development in pharmacy students. Shark Tank style presentations in programmes, implemented either virtually or face-toface, are a useful tool for institutions to nurture IE spirit among students. Like other pop culture sensations of the past, the popularity of Shark Tank may wane over time, but the IE skills and attitudes gained by students from such activities could flourish for a lifetime.

\section{Conflict of Interest}

The authors declare no conflict of interest.

\section{Source of Funding}

The authors did not receive any funding.

\section{References}

Accreditation Council for Pharmacy Education. (2017). Accreditation standards and key elements for the professional program in pharmacy leading to the doctor of pharmacy degree, Standards 2016. https://www.acpeaccredit.org/pdf/ACPEStandards2016Released.pdf. Accessed 27 November 2021

Baker, M.J., Zomorodi, M. (2018). Welcome to the clinical nurse leader shark tank. Journal of Nursing Education. 57(10), 631-632. https://doi.org/10.3928/0148483420180921-14

Braun, V., Clarke, V. (2006). Using thematic analysis in psychology. Qualitative Research in Psychology. 3(2), 77101. https://doi.org/10.1191/1478088706qp063oa

Brazeau, G. (2013). Entrepreneurial spirit in pharmacy. American Journal of Pharmaceutical Education. 77(5), Article 88. https://doi.org/10.5688/ajpe77588

Center for the advancement of pharmaceutical education (CAPE). (2013). Center for the advancement of pharmaceutical education (CAPE) outcomes 2013. https://www.aacp.org/sites/default/files/201710/CAPEoutcomes2013\%20\%281\%29.pdf. Accessed 27 November 2021

Cofrancesco, J., Wright, S.M., Vohr, E., Ziegelstein, R.C. (2017). Creating an education shark tank to encourage and support educational scholarship and innovation. Academic Medicine. 92(11), 1578-1582.

https://doi.org/10.1097/ACM.0000000000001715

University of the Pacific. (2021). Entrepreneurial pharmacy practice program.

https://pharmacy.pacific.edu/pharmacy/entrepreneurial. Accessed 27 November 2021

Mercer University. (2021). Entrepreneurship track. https://pharmacy.mercer.edu/admissions/pharmd/entrepreneurship-track. Accessed 27 November 2021

Hermansen-Kobulnicky, C.J., Moss, C.L. (2004). Pharmacy student entrepreneurial orientation: A measure to identify potential pharmacy entrepreneurs. American Journal of Pharmaceutical Education. 68(5), Article 113. https://doi.org/10.5688/aj6805113

Hussain, A., Chau, J., Bang, H., Meyer, L., Islam, M.A. (2021). Readiness, reception, and performance of students in a communications course delivered amid the pandemic. American Journal of Pharmaceutical Education. (Accepted) https://doi.org/10.5688/ajpe8617

Huston, S.A. (2018). Factors associated with entrepreneurial intentions in doctor of pharmacy students. American Journal of Pharmaceutical Education. 82(9), Article 6355. https://doi.org/10.5688/ajpe6355

Presbyterian college school of pharmacy. (2021). Innovation-Entrepreneurship. A program of Presbyterian college school of pharmacy.

https://pharmacy.presby.edu/departmentsoffices/innovation-entrepreneurship. Accessed 27 November 2021 
Krejcie, R.V., Morgan, D.W. (1970). Determining sample size for research activities. Educational \& Psychological Measurement. 30(3), 607-610.

https://doi.org/10.1177/001316447003000308

Laverty, G., Hanna, L.A., Haughey, S., Hughes, C. (2015). Developing entrepreneurial skills in pharmacy students. American Journal of Pharmaceutical Education. 79(7), Article 106. https://doi.org/10.5688/ajpe797106

Texas Pharmacy. (2021). Lester entrepreneurial scholars program. https://pharmacy.utexas.edu/degreesprograms/lester-entrepreneurial-scholars. Accessed 27 November 2021

Malcolm, D.R. (2016). Innovation and entrepreneurship: CAPE outcomes in action. Currents in Pharmacy Teaching \& Learning. 8(5), 587-588. https://doi.org/10.1016/j.cptl.2016.06.016

Mason HL, Assemi M, Brown B, et al. (2011). Report of the 2010-2011 Academic Affairs Standing Committee. American Journal of Pharmaceutical Education. 75(10), Article S12. https://doi.org/10.5688/ajpe7510S12

Mattingly, T.J., Mullins, C.D., Melendez, D.R., Boyden, K., Eddington, N.D. (2019a). A systematic review of entrepreneurship in pharmacy practice and education. American Journal of Pharmaceutical Education. 83(3), Article 7233. https://doi.org/10.5688/ajpe7520

Mattingly, T.J., Abdelwoud, M., Mullins, C.D. (2019b). Pharmapreneur - Defining a framework for entrepreneurship in pharmacy education. American Journal of Pharmaceutical Education. 83(10), Article 7548. https://doi.org/10.5688/ajpe7548
Mogul, A., Laughlin, E., Lynch, S. (2020). A co-curricular activity to introduce pharmacy students to the concepts of innovation and entrepreneurship. American Journal of Pharmaceutical Education. 84(8), Article 7805. https://doi.org/10.5688/ajpe7805

Neck, H.M., Greene, P.G. (2011). Entrepreneurship education: known worlds and new frontiers. Journal of Small Business Management. 49(1), 55-70. https://doi.org/10.1111/j.1540-627X.2010.00314.x

Phillips, A.C., Lewis, L.K., McEvoy, M.P., Galipeau, J., Glasziou, P., Moher, D., Tilson, J.K., Williams, M.T. (2016). Development and validation of the guideline for reporting evidence-based practice educational interventions and teaching (GREET). BMC Medical Education. 16(1), Article 237. https://doi.org/10.1186/s12909-016-0759-1

Rosenthal, M., Austin, Z., Tsuyuki, R.T. (2010). Are pharmacists the ultimate barrier to pharmacy practice change? Canadian Pharmacy Journal. 143(1), 37-42. https://doi.org/10.3821/1913-701X-143.1.37

Shane, S., Venkataraman, S. (2000). The promise of entrepreneurship as a field of research. Academy of Management Review. 25(1), 217-226. https://doi.org/10.2307/259271

Sweaney, A.M., Casper, K.A., Hoyt, C.D., Wehr, A.M. (2014). Student pharmacists' and recent graduates' perception of and interest in independent pharmacy ownership. Innovations in Pharmacy. 5(4), Article 182. https://doi.org/10.24926/iip.v5i4.364

\section{Appendix A: Sharks' representative questions to student presenters}

\begin{tabular}{|c|c|}
\hline Questions & \\
\hline \multirow[t]{3}{*}{ Product information } & How does your product work? \\
\hline & How did you come up with your idea? \\
\hline & What makes you think consumers would want this product? \\
\hline \multirow[t]{4}{*}{ Marketing plan } & Who is your target population? \\
\hline & How do you plan on advertising your product? \\
\hline & How much does it cost to make it? \\
\hline & How do you plan to distribute the product? \\
\hline \multirow[t]{4}{*}{ Associated Risks } & What are the risks associated with the venture? \\
\hline & What is your biggest obstacle in scaling up? \\
\hline & Can the service be provided indefinitely? \\
\hline & Does it require periodic updates and/or changes? \\
\hline \multirow[t]{3}{*}{ History/Background } & What approach have consumers resorted to in the past? \\
\hline & How is this product different from existing ones? \\
\hline & What were consumers' reactions to similar products in the past? \\
\hline
\end{tabular}

